\title{
Morphological Abnormalities in Rajidae Species (Chondrichthyes) From the Gulf of Gabès (Tunisia, Central Mediterranean Sea): What Causes?
}

\author{
Sondes Marouani*, Fekher Ben Jarray, Sami Karaa and Othman Jarboui \\ National Institute of Sciences and Technologies of the Sea (center of Sfax), Tunisia
}

*Corresponding author: Sondes Marouani, National Institute of Sciences and

Technologies of the Sea (center of Sfax), Tunisia.

Received Date: December 19, 2018

Published Date: January 04, 2019

\begin{abstract}
This study reports the occurrence of morphological abnormalities in four Rajidae specimens caught by a commercial trawler in the Gulf of Gabès (Tunisia, Central Mediterranean Sea): absence of tail and asymmetric pectoral fins in a female of the thornback ray Raja clavata Linnaeus, 1758 and absence of the caudal and dorsal fins in two female Raja clavata specimens and in one female Raja radula Delaroche, 1809 specimen. These cases of abnormality were described, commented and discussed.
\end{abstract}

Keywords: Raja clavate; Raja radula; Morphological abnormalities; Rajidae; Gulf of gabès; Central mediterranean sea

\section{Introduction}

The family Rajidae is the most diverse group of batoids, with 27 genera and about 245 species distributed worldwide [1].

The thornback ray Raja clavata Linnaeus, 1758, is a shallow water demersal skate found in the eastern Atlantic from Norway to South Africa, including the Mediterranean and Black Seas [2]. This species is widespread in the Mediterranean Sea and is the dominant skate in commercial landings [3]. The thornback ray occurs along the Tunisian coasts mainly in the Gulf of Gabès where it is caught throughout the year by commercial trawl fisheries as by catch [4].

The rough ray Raja radula Delaroche, 1809 is a relatively small skate endemic to the Mediterranean Sea [5]. The species abound along Tunisian coasts mainly in the Gulf of Gabès where it is taken as a by-catch by trawlers, demersal gill-nets and longlines and usually captures are marketed [6].

Morphological abnormalities have been reported in batoids, such as: conditions spinal and fin deformities in the axial skeleton [7], bicephalia [8], albinism [9], hermaphrodism [10] and the incomplete formation of some body parts [11-14], Morphological abnormalities were listed also in sharks [15-17]. The most common abnormalities in skates (Order Rajiformes) and rays (Order Myliobatiformes) is where the pectoral fins are not fused to the head. This type of abnormality had been recorded by different authors [14,18-23] for several species of Rajidae (Raja brachyuran, $R$. asterias, $R$. clavata, $R$. radula, $R$. radiata, $R$. miraletus, $R$. castelnaui, A. cyclophor, A. platana), Torpedinidae (Torpedo marmorata), Rhinobatidae (Rhynchobatus djiddensis), Gymnuridae (Gymnura poecilura), Potamotrygonidae (Potamotrygon motoro), Dasyatidae (Dasyatis longa, D. dipterura, D. akajei, Himantura uarnak, Pteroplatytrygon violacea).

Investigations conducted from early 2016 to date in the southern Tunisian waters to study the impact of deep-sea fishing on the resources and the benthic ecosystems of the Gulf of Gabès using an observer on board, allowed the capture of three female Raja clavata and one female $R$. radula malformed. These specimens were described in the present paper, with comments and discussion on morphological abnormalities reported in batoid species.

\section{Material and Methods}

The malformed specimens were caught by the commercial trawler "Baati" using a $24 \mathrm{~mm}$ stretched mesh size cod-end and operates in the Gulf of Gabès. The three malformed specimens of Raja clavata was caught at depth of 47 and at $50 \mathrm{~m}$, whereas the malformed $R$. radula was caught at depth of $47 \mathrm{~m}$ (Figure 1). 
Those specimens were identified according to Ebert and Compagno (2007) [1]. The total mass (TM) was weighted to the nearest $10 \mathrm{~g}$. Morphometric measurements were recorded to the nearest centimeter followed [24]. Photographs of the specimens were available.

\section{Results}

The three thornback ray specimens were females with a DW of $54.4 \mathrm{~cm}$ (Figure1), $34.8 \mathrm{~cm}$ (Figure 2) and $25.3 \mathrm{~cm}$ (Figure 3). respectively, and weighted $2130 \mathrm{~g}, 1834 \mathrm{~g}$ and $642.45 \mathrm{~g}$. respectively.
The female rough ray was $36 \mathrm{~cm}$ (Figure 4) in disk width and $1920.7 \mathrm{~g}$ in total mass.

The morphometric measurements of the specimens were shown in the (Table 1). The abnormality in specimens was focused in the posterior portion of the body. The R. clavata specimen (Figure 1) presented a morphological abnormality at tail which is absent as well as at the pectoral fins which were asymmetric (Figure2). Whereas the caudal and dorsal fins were lacking in $R$. clavata specimens (Figures 2\&3) and in the R. radula specimen (Figure 4).

Table 1

\begin{tabular}{|c|c|c|c|c|c|c|c|c|}
\hline Species & Raja clavata & & Raja clavata & & Raja clavata & & Raja radula & \\
\hline sex & Female & & Female & & Female & & Female & \\
\hline Total Mass (g) & 2130 & & 1834 & & 642.45 & & 1920.7 & \\
\hline Measurements & $\mathrm{cm}$ & $\% \mathrm{DL}$ & $\mathrm{cm}$ & $\% \mathrm{DL}$ & $\mathrm{cm}$ & $\% \mathrm{DL}$ & $\mathrm{cm}$ & $\% \mathrm{DL}$ \\
\hline Total length & ---- & --- & ---- & --- & ---- & --- & ---- & --- \\
\hline Disc length & 38.2 & & 46.5 & & 33.4 & & 27.5 & \\
\hline Disc width & 54.4 & 20.78 & 34.8 & 16.18 & 25.3 & 8.45 & 36 & 9.9 \\
\hline Snout to maximum width & 20.6 & 7.87 & 19.5 & 9.07 & 16 & 5.34 & 14 & 3.85 \\
\hline Snout length & 20.7 & 7.91 & 8.84 & 4.11 & 6.69 & 2.23 & 6.5 & 1.79 \\
\hline Snout to spiracle & 9.59 & 3.66 & 12.13 & 5.64 & 8.87 & 2.96 & 8.6 & 2.37 \\
\hline Head & 12.76 & 4.87 & 13.42 & 6.24 & 9.89 & 3.3 & 9 & 2.48 \\
\hline Orbit diameter & 2.21 & 0.84 & 2.1 & 0.98 & 1.61 & 0.54 & 1.55 & 0.43 \\
\hline Orbit and spiracle length & 3.31 & 1.26 & 3.29 & 1.53 & 2.3 & 0.77 & 2.4 & 0.66 \\
\hline Spiracle length & 2.09 & 0.8 & 2.21 & 1.03 & 1.63 & 0.54 & 1.34 & 0.37 \\
\hline Distance between orbits & 3.89 & 1.49 & 3.4 & 1.58 & 2.19 & 0.73 & 2.67 & 0.73 \\
\hline Distance between spiracles & 4.7 & 1.8 & 3.83 & 1.78 & 2.6 & 0.87 & 3.41 & 0.94 \\
\hline Snout to cloaca & 36.9 & 14.1 & 32.5 & 15.11 & 23.4 & 7.82 & 27.6 & 7.59 \\
\hline Ventral snout length & 8.45 & 3.23 & 7.67 & 3.57 & 5.92 & 1.98 & 5.27 & 1.45 \\
\hline Prenasal length & 7.42 & 2.83 & 7.87 & 3.66 & 5.27 & 1.76 & 4.32 & 1.19 \\
\hline Ventral head length & 19.41 & 7.41 & 17.61 & 8.19 & 13.28 & 4.44 & 13.32 & 3.66 \\
\hline Mouth width & 4.8 & 1.83 & 5.22 & 2.43 & 3.57 & 1.19 & 3.72 & 1.02 \\
\hline Distance between nostrils & 6.27 & 2.4 & 5.55 & 2.58 & 4.4 & 1.47 & 4.94 & 1.36 \\
\hline Nasal curtain length & 3.69 & 1.41 & 3.27 & 1.52 & 2.13 & 0.71 & 3.68 & 1.01 \\
\hline Width of first gill opening & 1.41 & 0.54 & 8.4 & 3.91 & 7 & 2.34 & 0.91 & 0.25 \\
\hline Width of fifth gill opening & 1.21 & 0.46 & 9.2 & 4.28 & 7.1 & 2.37 & 0.64 & 0.18 \\
\hline Distance between first gill openings & 11.74 & 4.48 & 10.55 & 4.91 & 7.57 & 2.53 & 7.96 & 2.19 \\
\hline Distance between fifth gill openings & 5.91 & 2.26 & 5.9 & 2.74 & 3.78 & 1.26 & 3.82 & 1.05 \\
\hline Length of anterior pelvic lobe & 7.83 & 2.99 & 7.61 & 3.54 & 5.79 & 1.93 & 6.86 & 1.89 \\
\hline Length of posterior pelvic lobe & 11.36 & 4.34 & 10.14 & 4.72 & 8.05 & 2.69 & 10.37 & 2.85 \\
\hline Pelvic base width & 10.95 & 4.18 & 6.11 & 2.84 & 4.3 & 1.44 & 6 & 1.65 \\
\hline Length of pectoral fin (right) & 25.2 & 9.63 & 2.63 & 1.22 & 1.99 & 0.66 & 2 & 0.55 \\
\hline Length of pectoral fin (left) & 26 & 9.93 & 2.55 & 1.19 & 1.74 & 0.58 & 1.1 & 0.3 \\
\hline
\end{tabular}




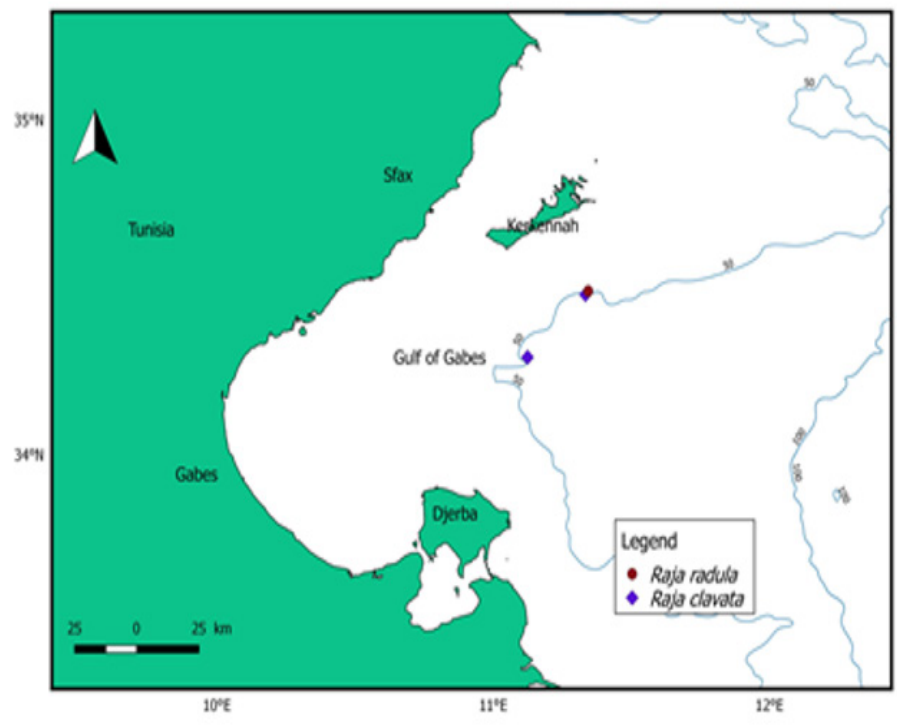

Figure 1: Sample display sequences in which the prime-probe couplet on the left depicts an ignored repetition (negative priming) trial sequence, whereas the one on the right depicts a control sequence of trials.
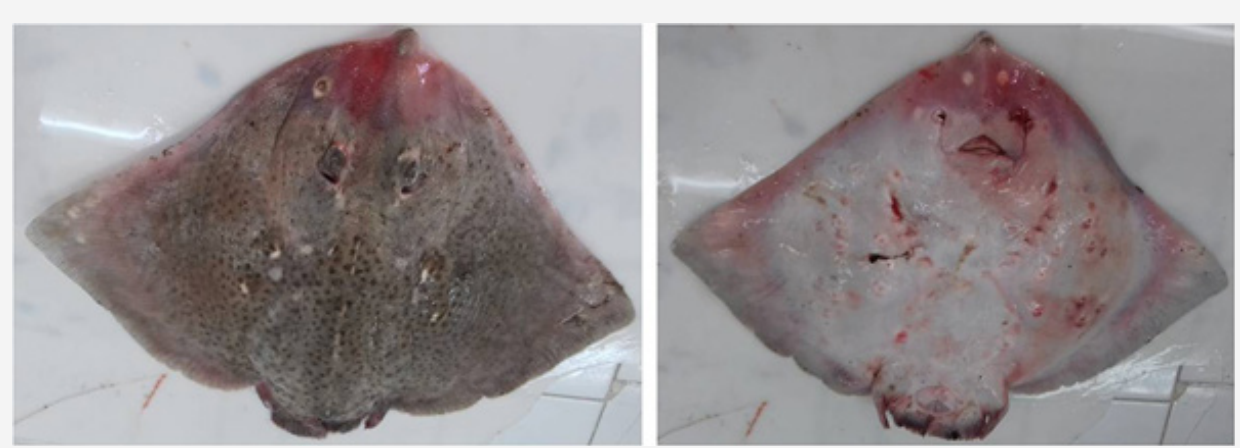

Figure 2: Raja clavata Linnaeus 1758, (left) dorsal face (right) ventral face from the Gulf of Gabès.
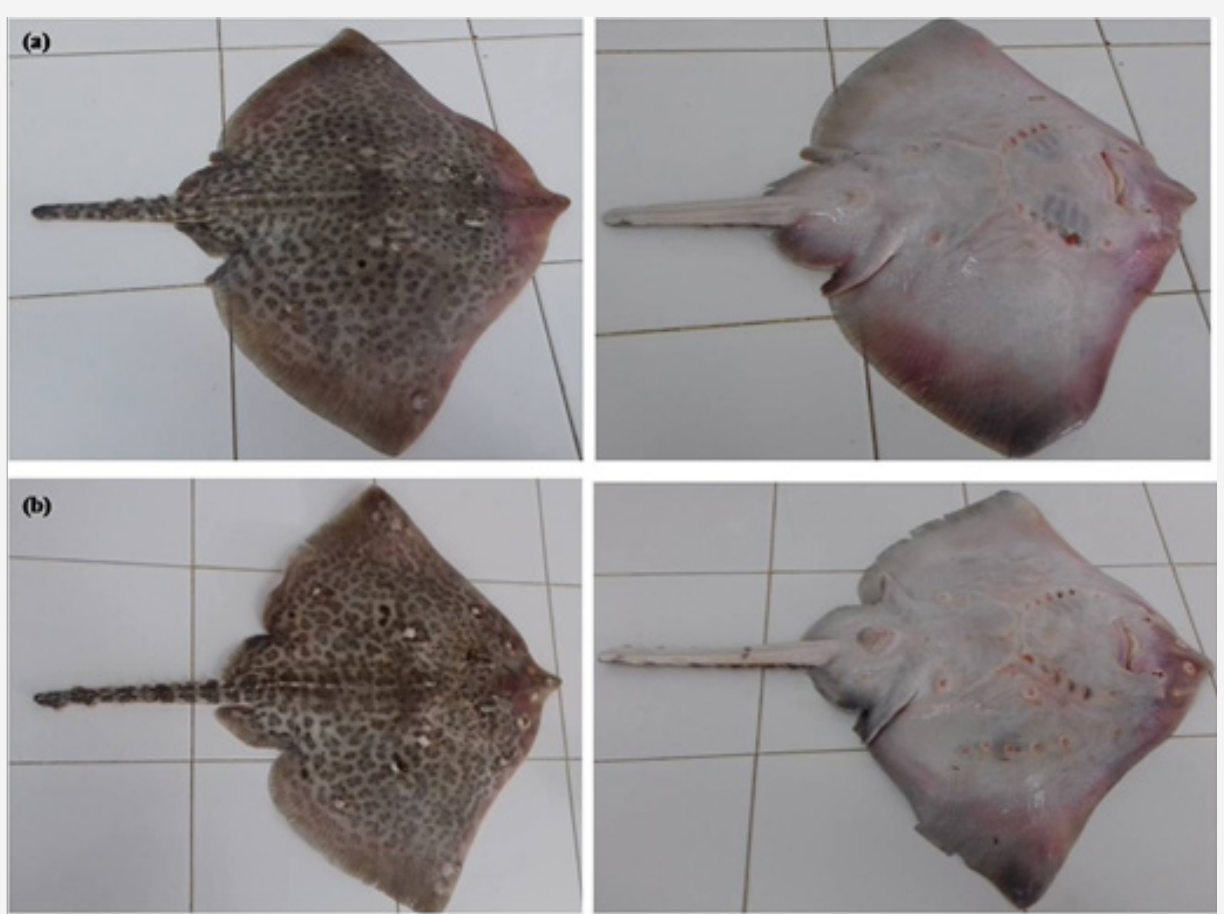

Figure 3: (a) $34.8 \mathrm{~cm}$ DW and (b) 25.3.cm DW Raja clavata Linnaeus 1758, (left) dorsal face (right) ventral face and (b) from the Gulf of Gabès. 


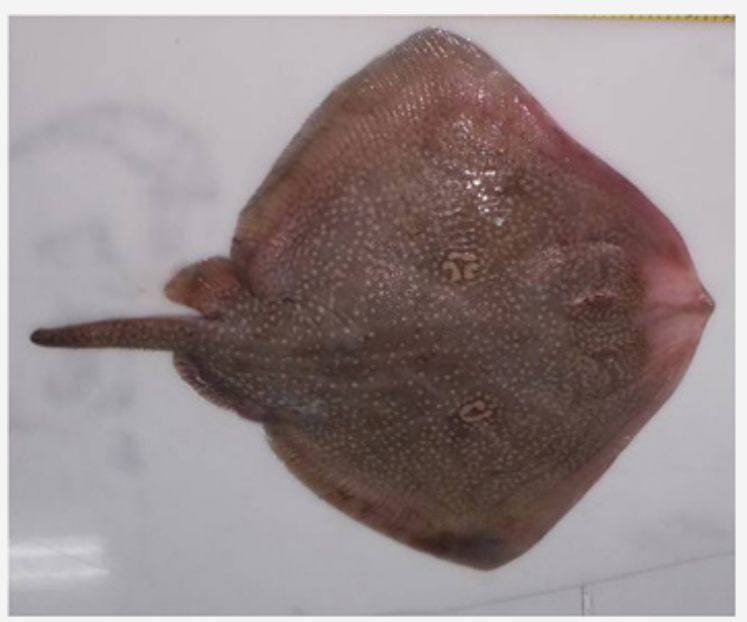

Figure 4: Raja radula Delaroche, 1809 from the Gulf of Gabès.

\section{Discussion}

The present report contributes with information about the presence of an abnormality in females of $\mathrm{R}$. clavata and $\mathrm{R}$. radula. This morphological abnormality is not due to an injury as it is generally the case in skates [25]. No scar was visible and all the posterior part was covered by pigmented skin.

Ribeiro-Prado, et al. [10] listed all morphological abnormalities recorded to date in skates and rays, and noted that abnormalities occurred in disc, with pectoral fins non-adherent to the head being the most recorded one. The later not only concerned skates but also rays and rarely torpedinids. A case of abnormality in $R$. radula was reported by Capapé C, et al. [26]. Another case of morphological abnormality in tail was observed in a common torpedo T. torpedo in Tunisian waters, the specimen exhibiting a surnumerary dorsal fin [27]. Recently, Capapé C, et al. [28] noted tail abnormality in three specimens of Raja clavata captured off the Syrian coast; a juvenile male with an ecaudated tail reduced to a stump like structure and two other female and male adults without dorsal and caudal fins.

Based on the reported median disc width at maturity for the thornback ray and the rough ray [29], those animals were mature and captured alive. Therefore, we assume the adaption of the specimens for the anomaly and that these abnormalities in tail and asymmetric fins did not prevent the individual from obtaining good food supplies and it appears that these abnormalities did not affect the development of the specimen and it reached similar parameters and swimming activities than the normal ones.

Congenital abnormalities are usually linked to different causes as: endogamy [30], parasites [31] or with exposure to environmental degradation or pollution of the mother [32].

The malformation reported here seems to be derived from the failure of the anterior lobes of the pectorals fins to join with the head during embryonic development [11] however the cause (or causes) of this condition remains unknown.

Unfortunately, this study cannot be conclusive about the causes of this specifically malformation and further studies should be done on this and other species to identify their possible causes.

\section{Acknowledgment}

The authors are especially grateful to all the staff of the trawler "Baati", with whom works the observer on board, for their help and assistance.

\section{Conflict of Interest}

No conflict of interest.

\section{References}

1. Ebert DA, Compagno LJV (2007) Biodiversity and systematics of skates (Chondrichthyes: Rajiformes: Rajoidei). Environ Biol Fish, 80 111-124.

2. Stehmann M, Burkel DL, Rajidae, Whitehead PJP, Bauchot ML, et al. (1984) Fishes of the North-eastern Atlantic and the Mediterranean 163196.

3. Abella A J, Serena F (2005) Comparison of elasmobranch catches from research Trawl surveys and commercial landings at port of Viareggio, Italy, in the last decade. J Northwest Atl Fish Sci V35, art. 23.

4. Kadri H, S Marouani, B Saidi, Bradai MN, Bouaïn A, et al. (2014) Age, growth, sexual maturity and reproduction of the thornback ray, Raja clavata (L), of the Gulf of Gabès (south-central Mediterranean Sea). Mar Biol Res 10 (4): 416-425.

5. Serena F, Mancusi C, Barone M (2010) Field identification guide to the skates (Rajidae) of the Mediterranean Sea. In: Guidelines for data collection and analysis. Biologia Marina Mediterranea (Eds), 17 pp. 204.

6. Kadri H, S Marouani, B Saidi, Bradai MN, Bouaïn A, et al. (2014) Age, growth, sexual maturity and reproduction of the thornback ray, Raja clavata (L), of the Gulf of Gabès (south-central Mediterranean Sea). Mar Biol Res 10 (4): 416-425.

7. Du Buit MH (1978) Quelques anomalies anatomiques chez les Raies. Bull de l'Office national des Pêches de Tunisie 2: 89-96.

8. Castro Aguirre JL, Torres-Villegas JR (1979) Sobre un caso de bicefalia funcional en Rhinoptera steindachneri Evermann \& Jenkins (Chondrichthyes, Elasmobranchii, Batoidea), capturado en la costa occidental de Baja California, Mexico. Cienc Mar 6: 27-41.

9. Sandoval Castillo JE, Mariano Melendez C, Villavicencio Garayzar C (2006) New records of albinism in two elasmobranchs: the tiger shark Galeocerdo cuvier and the giant electric ray Narcine entemedor. Cybium 30(2): 191-192.

10. Ribeiro Prado CC, Oddone MC, Conzalez MMB, Ferreira de Amorim A, Capapé C (2008) Morphological abnormalities in skates and rays (Chondrichthyes) from off Southeastern Brazil. Arquivos de Ciências do Mar del Fortaleza 41(2): 21-28.

11. Templeman W (1965) Some abnormalities in skates (Raja) of the Newfoundland area. J Fish Res Board Can 22(1): 237-238.

12. Forster GR (1967) A note on two rays lacking part of the snout. J Mar Biol Assoc UK 47(3): 499-500.

13. El Kamel O, Mnasri N, Ben Souissi J, Boumaïza M, Ben Amor MM et al. (2009) Inventory of elasmobranch species caught in the Lagoon of Bizerte (north-eastern Tunisia, central Mediterranean). Panam JAS 4(4): 383-412.

14. Escobar Sánchez O, Galván Magaña F, Downton Hoffmann CA, Carrera Fernández M, Alatorre Ramírez VG (2009) First record of a morphological abnormality in the longtail stingray Dasyatis longa (Myliobatiformes: Dasyatidae) in the Gulf of California, Mexico. Mar Biodivers Rec 2: e26.

15. Barrull J, Mate I, Bueno M (2002) Presence of atypical characteristics in a specimen of small-spotted catshark Scyliorhinus canicula (Linnaeus, 1758) caught in the Mediterranean. Ann Ser Hist Nat 12(1): 23-26.

16. Saïdi B, Bradai MN, Marouani S, Guélorget O, Capapé C (2006) A typical characteristics of an albino embryo of Carcharhinus plumbeus (Chondrichthyes: Carcharhinidae) from the Gulf of Gabès (southern Tunisia). Acta Adriat 47(2): 167-174. 
17. Mancini PL, Casas AL, Amorim AF (2006) Morphological abnormalities in a blue shark Prionace glauca (Chondrichthyes: Carcharhinidae) foetus from southern Brazil. J Fish Biol 69(6): 1881-1884.

18. Honma Y, Sugihara C (1971) A stingray, Dasyatis akajaei, with aberrant pectoral fins from the Japan Sea. Jap J Ichtyol 18(1): 187-189.

19. Lamilla J, Pequeño G, IU Kong (1995) Dasyatis brevis (Garman, 1880) segunda especie de Dasyatidae registrada para Chile (Chondrichthyes, Myliobatiformes). Estud oceanol 14: 23-27.

20. Rosa RS, Gomes UL, Gadig OBF (1996) Um caso de teratogenia na raia de água doce Potamotrygon motoro (Natterer in Muller \& Henle, 1841) (Chondrichthyes: Potamotrygonidae). Rev Nordest 11: 125-132.

21. Oldfield R (2005) Biology, husbandry, and reprodution of freshwater stingrays. TFH 53(12): 114-116.

22. Ribeiro-Prado CC, Oddone MC, Gonzalez MMB, Amorim AF, Capapé C (2009) An abnormal hermaphrodite pelagic stingray Pteroplatytrygon violacea (Dasyatidae) captured off the southern coast of Brazil. Cah Biol Mar 50: 91-96.

23. Blanco Parra MP, Niño Torres CA (2011) Morphological abnormality in a diamond stingray, Dasyatis dipterura (Jordan \& Gilbert, 1880) (Chondrichthyes: Dasyatidae), from the Gulf of California, Mexico. Cah Biol Mar 52(3): 357-360.

24. Last PR, White WT, Pogonoski JJ, Gledhill DC (2008) New Australian skates (Batoidea: Rajoidei) background and methodology. CSIRO Marine \& Atmospheric Research, Australia, p. 187.

25. Mnasri N, Boumaïza M, Capapé C (2009) Morphological data, observations and occurrence of a rare skate, Leucoraja circularis
(Chondrichthyes: Rajidae), off the northern coast of Tunisia (central Mediterranean). Panam JAS 4(1): 70-78.

26. Capapé C, Pantoustier C (1975) Anomalies chez quelques Sélaciens des côtes tunisiennes. Arch Inst Pasteur de Tunis 52(3): 251-260.

27. Ben Brahim R, Capapé C (1997) Nageoire dorsale supplémentaire chez une torpille ocellée, Torpedo torpedo des eaux tunisiennes (Méditerranée Centrale). Cybium 21(2): 223-225.

28. Capapé C, Ali M, Saad A, Alkusairy H, Reynaud C (2015) A typical characteristics in the longnosed skate Dipturus oxyrinchus (Linnaeus, 1758) from the coast of Syria (Eastern Mediterranean). Thalass Salentina 37: 71-80.

29. Kadri H (2013) Les Rajidae du Golfe de Gabès : Systématique et écobiologie de cinq espèces de raie: Raja clavata, Raja miraletus, Raja radula, Dipturus oxyrinchus et Rostroraja alba. PhD Thesis University of Sfax, Tunisia.

30. Sari F, Heinrich M, Meyer W, Braus GH, Irniger S ( 2008) The C-terminal region of the meiosis-specific protein kinase Ime 2 mediates protein instability and is required for normal spore formation in budding yeast. J Mol Biol 378 (1): 31-43.

31. Kelly DW, Thomas H, Thieltges DW, Poulin R, Tompkins DM (2010) Trematode infection causes malformations and population effects in a declining New Zealand fish. J Anim Ecol 79(2): 445-542.

32. Klumpp DW, Humphrey C, Huasheng H, Tao F (2002) Toxic contaminants and their biological effects in coastal waters of Xiamen, China. II. Biomarkers and embryo malformation rates as indicators of pollution stress in fish. Mar Pollut Bull 44(8): 761-769. 